\title{
Effect of penicillamine on the titre of the rheumatoid factor: a historical perspective
}

\author{
Evelyn V Hess, Morris Ziff
}

Rheumatologists are closet historians, our modern history is relatively short, and the drugs with which we treat patients are of recent vintage but better understood with every passing year. Penicillamine now has a definite place in the management of rheumatoid arthritis and other disorders.

Deutsch and Morton (1957) showed that cysteine and mercaptoethanol converted macroglobulin to molecular entities having sedimentation constants near that of $7 \mathrm{~S} \gamma$ globulin. ${ }^{1}$ Similar results were obtained by Glenchur, Zinneman, and Briggs (1958). ${ }^{2}$ Penicillamine was shown to have a similar effect in vitro by Bloch, Prasad, and Anastasi (1958) although these authors ${ }^{3}$ and Levine, Hammack, and Frommeyer (1960) found no obvious clinical benefit from this drug in four patients with Waldenström's macroglobulinaemia. ${ }^{4}$ Symptomatic relief, however, was reported by Ritzmann, Coleman, and Levin (1960) when penicillamine was given to a patient with a cold agglutinin in the form of a macroglobulin. ${ }^{5}$ It was also noted that this patient improved clinically after intravenous administration of large doses of penicillin. Incubation of the serum with penicillamine and penicillin $G$ resulted in substantial lowering of the cold agglutinin titre.

In 1960 Dresner and Trombly reported in vitro inhibition by penicillamine of the latex fixation test using the inhibition technique on euglobulin fractions of high titre serum samples. ${ }^{6}$ A transitory in vivo inhibition was noted in four of seven patients given penicillamine for one to 10 days. Griffin, Ulloa, Johnston, and Holley (1960) also showed an in vitro effect with penicillamine and, using the whole serum latex fixation procedure, noted an in vivo fall in titre with coincident clinical improvement in some patients treated for 10 days. ${ }^{?}$

In 1959 and 1960, when I had a travelling fellowship of the Empire Rheumatism Council at the rheumatic diseases unit of the University of Texas Southwestern Medical School, Dallas, Texas with Dr Morris Ziff, we decided to treat five patients with rheumatoid arthritis with penicillamine for extended periods because of the observations referred to above. The five patients (three men, two women) all had classical rheumatoid arthritis and extremely high titres of rheumatoid factor by the sensitised sheep cell agglutination test. Four of the patients had subcutaneous nodules and two diffuse arteritis.
They were treated with oral penicillamine $1 \cdot 5-$ $4 \mathrm{~g}$ daily for three to eight weeks. We thought our findings worthy of publication and the paper was submitted to the Annals of the Rheumatic Diseases in September 1960.

The summary from our paper was as follows:

1 The rheumatoid factor was degraded in vitro by concentrations of penicillamine, a sulphydryl compound, as low as $0.01 \mathrm{~mol} / 1$, as measured by agglutination of sensitised sheep cells.

2 Five patients were treated with oral penicillamine $1.5-4 \mathrm{~g}$ daily for three to eight weeks. In two, the sensitised sheep cell agglutination titre fell three tubes; in one, two tubes; and in two the titre was unchanged.

3 Significant clinical improvement during treatment was not seen. One patient showed evidence of pyridoxine deficiency requiring treatment.

In our discussion we stated that although the clinical findings were not very encouraging it may, nevertheless, be worthwhile to investigate further the effect of penicillamine on the clinical course of peripheral neuropathy and ischaemic ulceration of the skin in patients with rheumatoid arthritis and high titres of rheumatoid factor'.

As we all know, the investigator's life is full of ups and downs. A charming letter from Dr W S C Copeman, the editor of the Annals of the Rheumatic Diseases at that time was received which stated, 'With regard to your interesting paper on 'Effect of penicillamine on the titre of the rheumatoid factor', the report of our assessors suggests that you would have a much stronger paper and a better contribution to world literature if publication were delayed until at least another four or five patients had been studied. Furthermore, some method of assessing and depicting the clinical findings, with time, should be considered.' Unfortunately, no more penicillamine was then available as the manufacturer had stopped producing it, and we could not comply with the reviewers' and Dr Copeman's suggestions. Since those heady days penicillamine has become an accepted treatment for rheumatoid arthritis. In various review papers the first reference to the treatment of patients with rheumatoid arthritis is to Jaffe's excellent 1963 paper. $^{8}$ Dr Ziff and I thought it would be of interest to your readers to contemplate this vicissitude of clinical research as it happened 30 years ago.

We are sure that the Annals now always recognises worthwhile contributions to rheuma- 
tology and that the manuscripts of present and future fellows of the Arthritis and Rheumatism Council (which has replaced the good old Empire Rheumatism Council) will always find their rightful place in the pages of Will Copeman's proud old journal.

1 Deutsch H F, Morton J I. Dissociation of human serum macroglobulins. Science 1957; 125: 600-1.

2 Glenchur H, Zinneman H H, Briggs DR. Macroglobulinemia: report of two cases. Ann Intern Med 1958; 48: 1055-69.

3 Bloch H S, Prasad A, Anastasi A. [abstract]. Proceedings of the Central Society for Clinical Research 1958; 31: 12.
4 Levine M A, Hammack W J, Frommeyer W B. Treatment of macroglobulinemia with penicillamine [abstract]. Clin Res 1960; 8: 54

5 Ritzmann S E, Coleman S L, Levin W C. The effect of some mercaptanes upon a macrocryogel globulin; modifications mercaptanes upon a macrocryogel globulin; modifications Invest 1960; 39: 1320-9.

6 Dresner E, Trombly P. Chemical dissociation of the rheumatoid factor in vitro and in vivo [abstract]. Clin Res 1960;8 16.

7 Griffin S W, Ulloa H M, Johnston M L, Holley H L. In vivo effect of penicillamine on circulating rheumatoid factor (nervous and connective tissue) [abstract]. Clin Res 1960; 8: 87 .

8 Jaffe I A. Comparison of the effect of plasmapheresis and penicillamine on the level of circulating rheumatoid factor. Ann Rheum Dis 1963; 22: 71-6. 